\title{
Effects of temperature on infectivity and of commercial freezing on survival of the North American strain of viral hemorrhagic septicemia virus (VHSV)
}

\author{
Kristen D. Arkush ${ }^{1, *}$, Holly L. Mendonca ${ }^{1}$, Anne M. McBride ${ }^{1}$, Susan Yun ${ }^{2}$, \\ Terry S. McDowell ${ }^{2}$, Ronald P. Hedrick ${ }^{2}$ \\ ${ }^{1}$ Bodega Marine Laboratory, PO Box 247, Bodega Bay, California 94923, USA \\ ${ }^{2}$ Department of Medicine and Epidemiology, School of Veterinary Medicine, University of California, \\ One Shields Avenue, Davis, California 95616, USA
}

\begin{abstract}
Temperature affected the growth of the North American strain of viral hemorrhagic septicemia virus (VHSV) in experimentally infected cell cultures and in Pacific sardine Sardinops sagax. In addition, commercial freezing significantly reduced the infectivity of VHSV in tissues of experimentally infected sardine. Isolates of VHSV representing the geographic range of North American VHSV replicated in the EPC (Epithelioma papulosum cyprini) cell line at 10,15 and $20^{\circ} \mathrm{C}$, but the more northern isolates from British Columbia, Canada, demonstrated significantly reduced growth at $20^{\circ} \mathrm{C}$ compared to VHSV from more southern locations $(p<0.001)$. An injection challenge of Pacific sardine with VHSV from California resulted in $66.7 \%$ mortality at a seawater temperature of $13^{\circ} \mathrm{C}$ compared to $6.7 \%$ at $20^{\circ} \mathrm{C}$. Commercial blast-freezing of sardine experimentally infected with VHSV reduced median concentrations of virus in the kidney and spleen from $5.25 \times 10^{6}$ to $5.5 \times 10^{3}$ pfu (plaque-forming units) $\mathrm{g}^{-1}$. Decreased growth of the California isolate of VHSV at higher temperatures following experimental infection of the sardine and reduced virus survival following commercial freezing of infected sardine are factors that would lessen the risk of transmission of VHSV through frozen baitfishes.
\end{abstract}

KEY WORDS: VHSV $\cdot$ Baitfishes $\cdot$ Sardine $\cdot$ Temperature

\section{INTRODUCTION}

Viral hemorrhagic septicemia virus (VHSV) has been well documented as the cause of both acute and chronic infections in salmonids and more recently in a variety of marine fishes (Meyers \& Winton 1995). The North American strain of the virus has been reported as the cause of mass kills of pelagic marine fishes including the Pacific herring Clupea pallasi in Alaska (Meyers et al. 1999) and the sardine Sardinops sagax in British Columbia, Canada (Hedrick et al. 2003). The North American VHSV has also been recovered from a range of marine fish species, often in the absence of overt disease (Meyers \& Winton 1995, Amos et al. 1998). Among the marine fish hosts, the Pacific herring has been found to harbor the virus over a wide geographic area in the Pacific Northwest, with and without disease signs, suggesting that this species may be a major marine reservoir for VHSV (Meyers et al. 1994, Hershberger et al. 1999). The recent extension of the geographic range of the North American strain of VHSV to Oregon and California (Hedrick et al. 2003) and host-extension to the Pacific sardine further support the role of highly migratory pelagic species as marine reservoirs of the virus. 
The Pacific or California sardine of the California Current is a coastal pelagic species capable of migrations of over $2000 \mathrm{~km}$, with a range along the North American coast extending from southern Alaska $\left(57^{\circ} \mathrm{N}\right)$ to the southern tip of Baja California Sur $\left(23^{\circ} \mathrm{N}\right)$ and into the Gulf of California (McFarlane et al. 2002). Identical G-gene sequences of VHSV isolates from sardine in California and British Columbia suggest that the sardine is capable of carrying the virus throughout its range, but a low prevalence of the virus $(<8 \%$ in the California sardine tested) and absence of lesions in fish collected off the coasts of Oregon and California may indicate that environmental conditions, including water temperature, are likely key factors in disease outbreaks observed in juveniles and adults in colder Canadian waters (Hedrick et al. 2003). The large migratory routes between southern and northern waters expose the Pacific sardine to water temperatures ranging from 10 to $26^{\circ} \mathrm{C}$ (Wolf et al. 2001). The effects of these temperature changes on the transmission, replication and persistence of VHSV infections in the sardine are currently unknown.

Concerns by several countries exist over the risk of exotic fish-virus introductions with the movement of wild and cultured bait (Biosecurity Australia 2002). Whereas transport of cultured baitfish species in the United States is usually subject to state and federal fish health regulations, the harvesting and subsequent movement of wild baitfishes is largely unregulated, despite the significant numbers moved both interstate and through international trade (Goodwin et al. 2004). Magdalena Bay, near the tip of Mexico's Baja California Peninsula, is considered an important spawning area for much of the North American Pacific sardine population, and an estimated 40000 to $60000 \mathrm{t}$ of sardine are harvested and sold by Mexican fishermen, principally to provide feed for captive bluefin tuna Thunnus maccoyii located offshore along Baja (Dalton 2004). Off the coast of California, Pacific sardine are harvested and then shipped frozen to Australia for use as bait for commercial and recreational fishing and as a feed source for another captive bluefin tuna aquaculture industry. Sardine from California are an important commodity especially in seasons when local Australian pilchards are unavailable. Since the mid-1990's, over $250000 \mathrm{t}$ of baitfish have been exported to Australia for use in the tuna-farming industry, at an approximate value of 12 million US dollars annually. Examinations of marine fishes, including pilchards (sardine) in Australia have not demonstrated the presence of VHSV, and thus measures to prevent the potential entry of the virus have been employed (Biosecurity Australia 2002). However, key scientific data to better evaluate the potential risk of VHSV transmission via frozen baitfish importation is currently not available.
In this report, we present results of in vivo and in vitro experiments examining the effect of temperature on the stability and replication of the North American strain of VHSV. The studies were conducted to provide information needed to assess potential transmission risks of VHSV with movements of infected baitfishes.

\section{MATERIALS AND METHODS}

In vitro replication of virus isolates at varying temperatures. Replicate, 12-well culture plates of EPC (Epithelioma papulosum cyprini) cells (Fijan et al. 1983) were pretreated with polyethylene glycol (PEG) as described by Batts \& Winton (1989), and then inoculated with a 10-fold dilution series of each VHSV isolate that had been passaged 1 to 2 times in cell culture at multiplicities of infection (MOI) of approximately 0.01 to 0.05 . The isolates examined included BC-h-99 from herring in British Columbia in 1999 (Passage 2), BC-s-99 from sardine in British Columbia in 1999 (Passage 2), BC-s-02 from sardine in British Columbia in 2002 (Passage 2), C-m-01 from mackerel Scomber japonicus in California in 2001 (Passage 1), C-s-01 from sardine in California in 2001 (Passage 2), CMA-s02 from sardine in Malibu California in 2002 (Passage 1), CML-s-02 from sardine in Moss Landing California in 2002 (Passage 2), and O-e-01 from eulachon Thaleichthys pacificus in Oregon in 2001 (Passage 2). The plates were held at $10,15,20$ or $25^{\circ} \mathrm{C}$ for $1 \mathrm{~h}$; each well was then filled with minimal essential medium (MEM) supplemented with $2 \%$ fetal bovine serum (MEM-2), $50 \mathrm{IU}$ penicillin $\mathrm{ml}^{-1}, 50 \mathrm{mg}$ streptomycin $\mathrm{ml}^{-1}, 20 \mathrm{mM}$ l-glutamine and $0.75 \%(\mathrm{w} / \mathrm{v})$ methylcellulose, buffered with both $1 \mathrm{M}$ N-2-hydroxyethylpiperazine-N'-2ethane sulfonic acid (HEPES) and $1 \mathrm{~N}$ sodium hydroxide (MEM-2 + HEPES). The plates were incubated at the respective temperature for $6 \mathrm{~d}$. All plates were then fixed and stained with $0.6 \%$ (w/v) crystal violet in a $60 \%$ formalin solution to reveal plaques for counting. Virus concentrations were expressed as plaque-forming units (pfu) $\mathrm{ml}^{-1}$. Differences in virus concentrations of each isolate at each temperature were compared by a 2 -way analysis of variance (Holm-Sidak method) using SigmaStat Version 3.0.

Source of fish. The live sardine used in these experiments were obtained from local bait-fishers. The fish were caught off the shore of Northern California and transferred to net-pen enclosures. Within $1 \mathrm{wk}$ of capture, the fish were transported to a pathogencontainment facility at the University of California Bodega Marine Laboratory, where they were held in 7121 tanks supplied with aerated, flow-through seawater at 12 to $13^{\circ} \mathrm{C}$. The sardines were fed twice daily 
with a commercial pelleted diet and live Artemia spp. At the time of exposure, the fish weighed approximately $95 \mathrm{~g}$.

Laboratory exposure to virus at varying water temperatures. A total of 50 sardine were divided into 4 tanks receiving flow-through seawater at $13^{\circ} \mathrm{C}$. We used 2 tanks containing 15 fish each for virus exposure, and 2 tanks of 10 fish each as unexposed controls. The water in one of each of the 'exposed' and 'control' tanks was gradually raised to $20^{\circ} \mathrm{C}$ at a rate of approximately $1^{\circ} \mathrm{C} \mathrm{h}^{-1} ; 6 \mathrm{~d}$ later, the fish in each exposed tank were inoculated with $6.3 \times 10^{7} \mathrm{pfu}$ CML-s-02 in $0.3 \mathrm{ml}$ MEM-2 by intraperitoneal injection, while fish in the control groups received $0.3 \mathrm{ml}$ MEM-2 alone. Throughout the $21 \mathrm{~d}$ experiment, all severely moribund or dead sardine were promptly removed from the tanks and processed for virus isolation. At the end of the experiment, 2 fish from each control tank and 5 from each exposed tank were sampled for virus isolation.

Effect of commercial freezing on virus concentrations in individual fish. The CML-S-02 isolate of VHSV was used for the in vivo studies. Cultures of EPC cells were inoculated with VHSV at an MOI of 0.01 and held at $15^{\circ} \mathrm{C}$. After 6 to $7 \mathrm{~d}$, when cytopathic effects were advanced, the cells and medium were collected. Procedures for isolation of the virus from fish following experimental exposures were identical to those previously described (OIE 2003). Sardine were inoculated with $4.65 \times 10^{7} \mathrm{pfu}$ of isolate CML-s-02 in $0.3 \mathrm{ml} \mathrm{MEM-2}$ by intraperitoneal injection. At $6 \mathrm{~d}$ post-exposure, 11 fish died and these were sampled for the virus immediately and then held on ice overnight. At $7 \mathrm{~d}$ post-exposure, all remaining fish $(\mathrm{n}=39)$ were killed and sampled for virus. Each fish was examined for the presence of VHSV by removal of a portion of the kidney and spleen. The incision on the abdomen was then sutured and a disk tag was attached for identification of each individual fish, and 50 exposed fish and 50 controls were packed on ice and transported to a commercial fishprocessing facility in Salinas, California. Holding and transport of the experimentally infected sardine were similar to those used for wild-caught sardines: sardine caught in the fishery are placed on ice or into refrigerated seawater (which results in their death shortly thereafter) and are then transported to the processing plant over a time period that is typically less than $8 \mathrm{~h}$. Upon arrival at the processor, the 50 experimentally infected sardine were placed in a bag within a plastic crate, to which uninfected fish were added for a total of $10 \mathrm{~kg}$ (the standard commercial unit size for freezing). The crate was placed on a rack in a commercial blastfreezer and subjected to freezing in a wind tunnel at $-40^{\circ} \mathrm{C}$ with a chill factor of $-90^{\circ} \mathrm{C}$ for $20 \mathrm{~h}$ to a core temperature for the frozen block of $-24^{\circ} \mathrm{C}$. The block was removed from the crate at the commercial freezingplant and transported on dry ice back to the laboratory. Upon arrival, the block was transferred to a freezer $\left(-20^{\circ} \mathrm{C}\right)$ and held there for $2 \mathrm{wk}$ to replicate commercial holding conditions and the minimum time between processing and feeding of the product in Australia. After $2 \mathrm{wk}$, all 50 exposed fish were thawed and virus extraction was repeated from the remaining portions of the kidney and spleen of each tagged fish. Tissue homogenates collected either prior to or after freezing were diluted and then used to inoculate EPC cells pretreated with polyethylene glycol as described previously. The plates were fixed and stained for counting plaques after $6 \mathrm{~d}$ at $15^{\circ} \mathrm{C}$. Concentrations of virus were calculated and expressed as $\mathrm{pfu} \mathrm{g}^{-1}$. Differences in viral titers before and after freezing were compared using a Wilcoxon signed-rank test.

\section{RESULTS AND DISCUSSION}

\section{In vitro replication of virus isolates at varying temperatures}

Temperature had a significant effect on virus growth, as evaluated by the number of plaques observed $6 \mathrm{~d}$ following inoculation of the EPC line ( $\mathrm{p}<0.001$ ). All VHSV isolates replicated at $10^{\circ} \mathrm{C}, 15^{\circ} \mathrm{C}$ and $20^{\circ} \mathrm{C}$, but not at $25^{\circ} \mathrm{C}$ (Fig. 1). In pairwise comparisons, the $3 \mathrm{VHSV}$ isolates from either sardine or herring in British Columbia showed significantly reduced growth at $20^{\circ} \mathrm{C}(\mathrm{p}<0.001)$ compared with isolates recovered from fishes off the coasts of Oregon and California $\left(2.0 \times 10^{4}\right.$ to $1.1 \times 10^{5} \mathrm{pfu} \mathrm{m}^{-1}$ for British Columbia fish versus $2.0 \times 10^{6}$ to $5.85 \times 10^{7} \mathrm{pfu} \mathrm{ml}^{-1}$ for California and Oregon fish).

Temperature may influence the outcome of VHSV infections by direct effects on virus replication (Castro et al. 2005) or indirect effects on the fish-host immune response to the virus (Avtalion et al. 1976). Prior studies with the European $F_{1}$ isolate of VHSV demonstrated that active replication occurred in cell cultures at temperatures ranging from 6 to $18^{\circ} \mathrm{C}$ and was optimal at $14^{\circ} \mathrm{C}$, with little or no growth observed at $22^{\circ} \mathrm{C}$ (de Kinkelin \& Scherrer 1970). In our trials, the North American VHSV strains demonstrated growth at 10 to $20^{\circ} \mathrm{C}$ with an optimum at $15^{\circ} \mathrm{C}$ and no growth at $25^{\circ} \mathrm{C}$ (Fig. 1). Selection for a temperature-tolerant or thermoresistant variant of a freshwater VHSV strain from Europe able to replicate at $25^{\circ} \mathrm{C}$ has been demonstrated (de Kinkelin et al. 1980). The virus selected by steadily increasing cell-culture incubation temperatures demonstrated clear differences from the wild-type virus with respect to virulence for trout and intracellular virion 

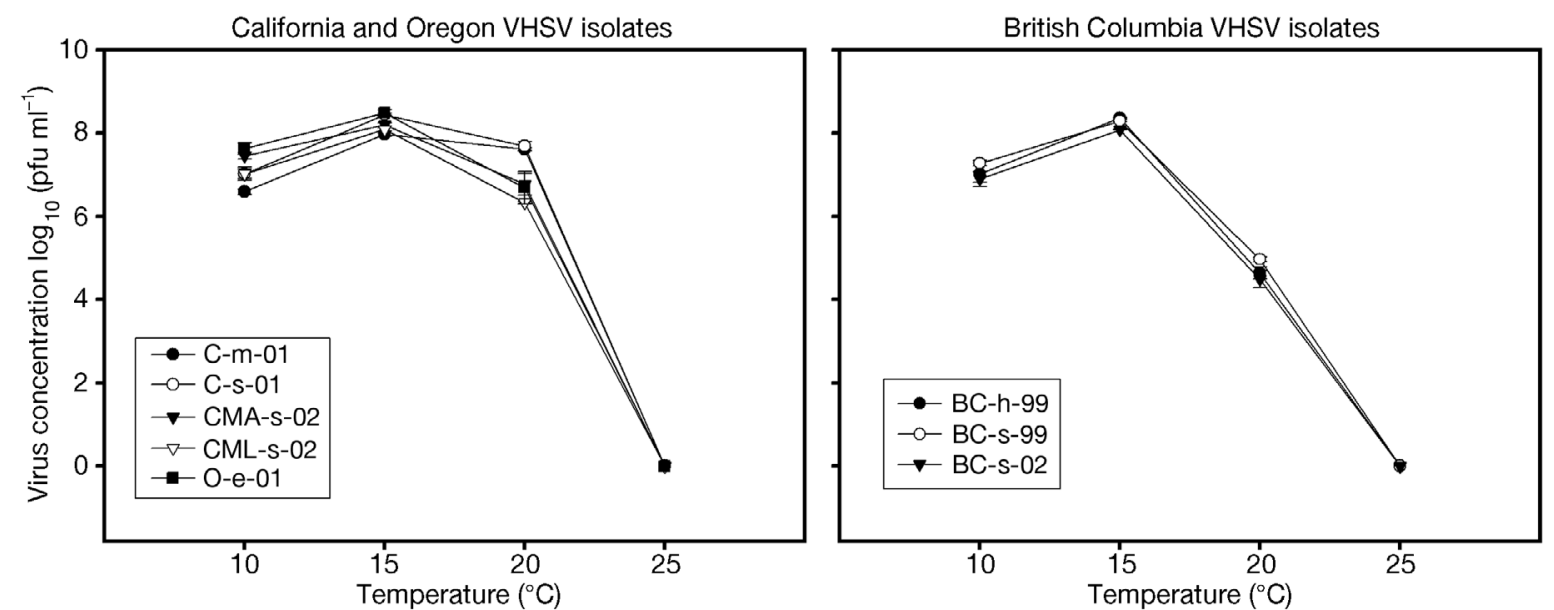

Fig. 1. Concentrations of viral hemorrhagic septicemia virus (VHSV) detected in cell-culture medium $6 \mathrm{~d}$ after inoculation of EPC cell line at 10,15, 20 or $25^{\circ} \mathrm{C}$. A total of 8 North American strains of VHSV from southern (California and Oregon, USA) and northern (British Columbia, Canada) latitudes were examined. Concentrations of virus are expressed as log(10) transformations of plaque-forming units (pfu) $\mathrm{ml}^{-1}$. BC-h-99: British Columbia herring Clupea pallasi 1999; BC-s-99: British Columbia sardine Sardinops sagax 1999; BC-s-02: British Columbia sardine 2002; C-m-01: California mackerel Scomber japonicus 2001; Cs-01: California sardine 2001; CMA-s-02: California sardine, Malibu 2002; CML-s-02: California sardine, Moss Landing 2002; O-e-01: Oregon eulachon Thaleichthys pacificus 2001

polypeptide synthesis (de Kinkelin et al. 1980). It is possible that North American strains of VHSV have acquired increased tolerances for growth at higher temperatures by more natural means. The migration of susceptible pelagic marine fishes between marine environments with significant water-temperature differences might encourage such selection of more thermotolerant isolates of VHSV. The better in vitro growth of VHSV from California sardine at $20^{\circ} \mathrm{C}$ compared to that of VHSV isolates from the cooler northern waters of British Columbia, Canada, may indeed be a result of such selection. The potential to select such a temperature variant or mutant from a pool of viruses found in a single fish is consistent with the 'quasi species' concept known for another novirhabdovirus - infectious hematopoietic necrosis virus (Emmenegger et al. 2003, Kurath et al. 2003).

\section{Laboratory exposure to virus at varying water temperatures}

Trials examining the effect of water temperature on VHSV infections in marine fishes also suggest that warmer temperatures $\left(20^{\circ} \mathrm{C}\right.$ and above) prevent the active replication and onset of disease observed at lower temperatures (Castric \& de Kinkelin 1984, Isshiki et al. 2002). In our trials, 10 of 15 sardine exposed to VHSV at $13^{\circ} \mathrm{C}$ and 1 of 15 exposed at $20^{\circ} \mathrm{C}$ died during the course of the experiment, and the virus was reisolated from all dead fish, with virus concentrations ranging from $1.26 \times 10^{5}$ to $1.56 \times 10^{8} \mathrm{pfu} \mathrm{g}^{-1}$ tissue (Table 1). None of the control sardine died during the
Table 1. Sardinops sagax. Day of death and tissue concentrations (plaque-forming units [pfu] $\mathrm{g}^{-1}$ fish tissue) of viral hemorrhagic septicemia virus (VHSV) among Pacific sardines injected with the virus and then held at water temperatures of 13 or $20^{\circ} \mathrm{C}$. nd: not detected

\begin{tabular}{|c|c|c|c|}
\hline $\begin{array}{l}\text { Fish } \\
\text { no. }\end{array}$ & $\begin{array}{c}\text { Death } \\
\text { (d post-exposure) }\end{array}$ & $\begin{array}{l}\text { Weight } \\
\text { (g) }\end{array}$ & $\begin{array}{l}\text { VHSV titer } \\
\left(\mathrm{pfu} \mathrm{g}^{-1}\right)\end{array}$ \\
\hline \multicolumn{4}{|l|}{$13^{\circ} \mathrm{C}$} \\
\hline \multicolumn{4}{|c|}{ Exposed } \\
\hline 1 & 2 & 100.3 & $4.60 \times 10^{7}$ \\
\hline 2 & 2 & 108.4 & $4.10 \times 10^{6}$ \\
\hline 3 & 2 & 64.5 & $1.79 \times 10^{6}$ \\
\hline 4 & 3 & 107.7 & $1.56 \times 10^{8}$ \\
\hline 5 & 5 & 75.6 & $8.55 \times 10^{7}$ \\
\hline 6 & 5 & 84.1 & $9.70 \times 10^{7}$ \\
\hline 7 & 5 & 97.1 & $4.10 \times 10^{7}$ \\
\hline 8 & 6 & 101.9 & $1.23 \times 10^{8}$ \\
\hline 9 & 6 & 105.1 & $1.45 \times 10^{8}$ \\
\hline 10 & 10 & 87.2 & $1.51 \times 10^{7}$ \\
\hline 11 & Alive at $21 \mathrm{~d}$ & 92.9 & nd \\
\hline 12 & Alive at $21 \mathrm{~d}$ & 96.8 & nd \\
\hline 13 & Alive at $21 \mathrm{~d}$ & 93.2 & nd \\
\hline 14 & Alive at $21 \mathrm{~d}$ & 93.7 & nd \\
\hline 15 & Alive at $21 \mathrm{~d}$ & 86.7 & nd \\
\hline \multicolumn{4}{|c|}{ Control } \\
\hline 1 & Alive at $21 \mathrm{~d}$ & 78.6 & nd \\
\hline 2 & Alive at $21 \mathrm{~d}$ & 85.6 & nd \\
\hline \multicolumn{4}{|l|}{$20^{\circ} \mathrm{C}$} \\
\hline \multicolumn{4}{|c|}{ Exposed } \\
\hline 1 & 3 & 114.7 & $1.26 \times 10^{5}$ \\
\hline 2 & Alive at $21 \mathrm{~d}$ & 83.6 & nd \\
\hline 3 & Alive at $21 \mathrm{~d}$ & 69.3 & nd \\
\hline 4 & Alive at $21 \mathrm{~d}$ & 66.4 & nd \\
\hline 5 & Alive at $21 \mathrm{~d}$ & 101.5 & nd \\
\hline 6 & Alive at $21 \mathrm{~d}$ & 102.0 & nd \\
\hline \multicolumn{4}{|c|}{ Control } \\
\hline 1 & Alive at $21 \mathrm{~d}$ & 71.1 & nd \\
\hline 2 & Alive at $21 \mathrm{~d}$ & 90.3 & nd \\
\hline
\end{tabular}


$21 \mathrm{~d}$ experiment. VHSV was not recovered from any of the fish sampled at the end of the experiment. All fish that died following injection with VHSV had signs consistent with infection reported in other marine fish species (Castric \& de Kinkelin 1984, Meyers et al. 1994, 1999, Kocan et al. 1997, Isshiki et al. 2001).

Based upon the results of our in vitro studies, we anticipated that the CML-s-02 isolate of VHSV would be capable of replication in sardine at $20^{\circ} \mathrm{C}$. Although 1 virus-injected fish did die at this temperature, most fish did not succumb to infection, and thus host immune-responses probably functioned to arrest and then eliminate the virus in sardines at this water temperature (de Kinkelin et al. 1982, Vestergård Jørgensen 1982). Although we did not evaluate the immune status of these fish prior to experimental exposure, the high mortality in the $13^{\circ} \mathrm{C}$ challenge group suggests that the population had not been naturally exposed prior to the experiments. In addition, and unlike the findings of Hershberger et al. (1999) in wild herring, we did not observe any mortality due to VHSV in the wild sardine following capture and holding prior to experimental challenge.

Results similar to those obtained in our sardine challenges were found following experimental infections of 2 marine fish species, the seabass Dicentrarchus labrax and the turbot Scophthalmus maximus, with a European isolate of VHSV: at a water temperature of $20^{\circ} \mathrm{C}$, no disease or mortality were observed, while at $12.5^{\circ} \mathrm{C}$ nearly all fish died of virus infection (Castric \& de Kinkelin 1984). Similarly, natural outbreaks of VHS in marine fishes have all been recorded at water temperatures less than $18^{\circ} \mathrm{C}$ (Meyers et al. 1994, 1999, Isshiki et al. 2001). These experimental trials and field observations suggest that warmer water temperatures $\left(>18^{\circ} \mathrm{C}\right)$ greatly reduce or even inhibit the transmission and development of VHSV infections in marine fishes.

Water temperature has also been shown to be a key factor in the stability of VHSV. A study with marine isolates of VHSV from Europe and North America demonstrated that stability was inversely correlated with temperature, with maximum survival at $4^{\circ} \mathrm{C}$ from 7 to $21 \mathrm{~d}$, compared to less than $7 \mathrm{~d}$ at 15 to $20^{\circ} \mathrm{C}$ (Parry \& Dixon 1997). Kocan et al. (2001) observed even less survival (maximum of $40 \mathrm{~h}$ ) of a North American VHSV in seawater at $15^{\circ} \mathrm{C}$. The growing season for tuna aquaculture off South Australia is typically between January and July. During this period, when tuna are actively fed imported baitfishes, the average sea temperature is 20 to $21^{\circ} \mathrm{C}$ in January, falling to 16 to $17^{\circ} \mathrm{C}$ by April and reaching 14 to $15^{\circ} \mathrm{C}$ by June. Also, there is relatively little variation in sea temperature between the various tuna-farming areas or at varying depths (Ramesh Perera, Australian Department of Fisheries, Agriculture and Forestry pers. comm.).

\section{Effect of commercial freezing on virus concentration}

Additional factors that may reduce the risk of transfer of VHSV with baitfishes include a naturally low prevalence of infection amongst fishes taken in the fishery and freezing procedures that significantly reduce the infectivity of virus present in these fishes. The prevalence of VHSV among Pacific sardine from the fishery was estimated to range from 0 to $4-8 \%$ (Hedrick et al. 2003). Sardines and other marine fishes involved in natural outbreaks of VHS are generally not part of the fishery, and these outbreaks are thought to be linked to unusually dense populations that experience some severe environmental stressors (Meyers et al. 1994, Hedrick et al. 2003). Virus concentrations in apparently healthy fishes are also 1000- to 10000 -fold less than that in fish with the active disease (Meyers et al. 1999). Lastly, freezing and then thawing of VHSVinfected fishes is suspected to further reduce concentrations of infectious virus that might reach the environment through baitfishes.

In our trials, commercial freezing significantly reduced concentrations of infectious virus present in sardine experimentally infected with the North American strain of VHSV (Table 2). All 50 fish tested harbored virus prior to freezing, with a median titer of 5.25 $\times 10^{6} \mathrm{pfu} \mathrm{g}^{-1}$ tissue (range: $7.38 \times 10^{3}$ to $6.71 \times 10^{8} \mathrm{pfu}$ $\mathrm{g}^{-1}$ ). After freezing, the median titer was $5.50 \times 10^{3} \mathrm{pfu}$ $\mathrm{g}^{-1}$ tissue (range: 0 to $1.07 \times 10^{7} \mathrm{pfu} \mathrm{g}^{-1}$ ). The difference between pre- and post-freeze-thaw, an approximate $99.9 \%$ reduction, was significant $(p<0.001)$. The data indicate that if there are relatively high concentrations of virus in the tissues at the time of initial freezing, the virus is more apt to be detected following freezing and thawing. A similar effect was described by Meyers et al. (1994), who found VHSV after 2 cycles of freezing and thawing the tissues of Pacific herring that had undergone a natural VHSV outbreak. That freezing and thawing may reduce infectivity by $90 \%$ or more was initially shown by de Kinkelin \& Scherrer (1970) with a freshwater European strain of VHSV, although virus stability was improved when serum was present in the freezing medium. Subsequent studies with marine fishes collected both in North America (Pacific Ocean) and Europe (Baltic Sea) suggest that when virus concentrations in the fish tissues are lower, virus recovery after freezing and thawing may be difficult (Meyers et al. 1999, Mortensen et al. 1999). Meyers et al. (1999) estimated that a single freeze-thaw cycle could reduce virus infectivity in fish tissues by up to 1000 fold. The results of our study, which is the first to examine actual commercial freezing, combined with the results of others indicate that the process of freezing and thawing significantly reduces infectious VHSV present in fish tissues. When concentrations of virus 
Table 2. Sardinops sagax. Concentrations (plaque-forming units [pfu $\mathrm{g}^{-1}$ fish tissue) of viral hemorrhagic septicemia virus (VHSV) detected in Pacific sardine following experimental inoculations with the virus. Concentrations of VHSV from the same fish were examined from portions of the kidney and spleen before and after commercial freezing. nd: not detected

\begin{tabular}{|c|c|c|c|}
\hline \multirow{2}{*}{$\begin{array}{l}\text { Fish } \\
\text { no. }\end{array}$} & \multicolumn{2}{|c|}{ Titer $\left(\mathrm{pfu} \mathrm{g}^{-1}\right)$} & \multirow[t]{2}{*}{$\%$ reduction } \\
\hline & Pre-freeze & Post-freeze & \\
\hline 1 & $5.75 \times 10^{6}$ & $8.63 \times 10^{3}$ & 99.850 \\
\hline 2 & $6.63 \times 10^{6}$ & $2.38 \times 10^{6}$ & 64.100 \\
\hline 3 & $4.75 \times 10^{6}$ & $1.59 \times 10^{4}$ & 99.670 \\
\hline 4 & $7.25 \times 10^{7}$ & $3.38 \times 10^{3}$ & 99.995 \\
\hline 5 & $1.86 \times 10^{7}$ & $4.00 \times 10^{3}$ & 99.900 \\
\hline 6 & $1.90 \times 10^{7}$ & $1.91 \times 10^{4}$ & 99.899 \\
\hline 7 & $7.25 \times 10^{7}$ & nd & 100.000 \\
\hline 8 & $2.21 \times 10^{7}$ & $1.85 \times 10^{4}$ & 99.916 \\
\hline 9 & $6.25 \times 10^{7}$ & $2.00 \times 10^{5}$ & 99.680 \\
\hline 10 & $7.63 \times 10^{7}$ & $4.38 \times 10^{4}$ & 99.943 \\
\hline 11 & $4.00 \times 10^{7}$ & nd & 100.000 \\
\hline 12 & $3.75 \times 10^{7}$ & $2.19 \times 10^{6}$ & 94.160 \\
\hline 13 & $3.88 \times 10^{6}$ & $5.05 \times 10^{4}$ & 98.698 \\
\hline 14 & $3.25 \times 10^{6}$ & $3.75 \times 10^{3}$ & 99.885 \\
\hline 15 & $2.48 \times 10^{6}$ & $2.50 \times 10^{3}$ & 99.899 \\
\hline 16 & $8.25 \times 10^{5}$ & $2.63 \times 10^{4}$ & 96.812 \\
\hline 17 & $2.53 \times 10^{6}$ & $3.25 \times 10^{3}$ & 99.872 \\
\hline 18 & $4.38 \times 10^{5}$ & $5.00 \times 10^{3}$ & 98.858 \\
\hline 19 & $7.38 \times 10^{3}$ & nd & 100.000 \\
\hline 20 & $1.53 \times 10^{8}$ & $7.50 \times 10^{3}$ & 99.995 \\
\hline 21 & $2.30 \times 10^{8}$ & $2.00 \times 10^{3}$ & 99.999 \\
\hline 22 & $9.38 \times 10^{4}$ & $1.25 \times 10^{2}$ & 99.867 \\
\hline 23 & $7.00 \times 10^{5}$ & $7.50 \times 10^{2}$ & 99.893 \\
\hline 24 & $9.75 \times 10^{7}$ & $2.38 \times 10^{3}$ & 99.998 \\
\hline 25 & $6.71 \times 10^{8}$ & $8.75 \times 10^{3}$ & 99.999 \\
\hline 26 & $1.43 \times 10^{7}$ & $1.75 \times 10^{3}$ & 99.988 \\
\hline 27 & $5.44 \times 10^{8}$ & $3.50 \times 10^{4}$ & 99.994 \\
\hline 28 & $1.20 \times 10^{8}$ & $6.75 \times 10^{6}$ & 94.375 \\
\hline 29 & $1.01 \times 10^{7}$ & $1.81 \times 10^{4}$ & 99.821 \\
\hline 30 & $3.16 \times 10^{7}$ & $1.07 \times 10^{7}$ & 66.139 \\
\hline 31 & $4.13 \times 10^{6}$ & $7.00 \times 10^{5}$ & 83.051 \\
\hline 32 & $4.63 \times 10^{6}$ & $3.88 \times 10^{5}$ & 91.620 \\
\hline 33 & $7.00 \times 10^{4}$ & $5.00 \times 10^{1}$ & 99.929 \\
\hline 34 & $7.25 \times 10^{6}$ & $8.50 \times 10^{3}$ & 99.883 \\
\hline 35 & $3.25 \times 10^{7}$ & $9.88 \times 10^{4}$ & 99.696 \\
\hline 36 & $1.08 \times 10^{6}$ & $6.00 \times 10^{3}$ & 99.444 \\
\hline 37 & $1.63 \times 10^{5}$ & $2.28 \times 10^{4}$ & 86.012 \\
\hline 38 & $4.75 \times 10^{6}$ & $3.50 \times 10^{3}$ & 99.926 \\
\hline 39 & $4.00 \times 10^{5}$ & $2.50 \times 10^{2}$ & 99.938 \\
\hline 40 & $3.60 \times 10^{8}$ & $4.88 \times 10^{4}$ & 99.986 \\
\hline 41 & $2.26 \times 10^{6}$ & nd & 100.000 \\
\hline 42 & $2.09 \times 10^{6}$ & $8.75 \times 10^{2}$ & 99.958 \\
\hline 43 & $6.75 \times 10^{6}$ & $2.50 \times 10^{3}$ & 99.963 \\
\hline 44 & $2.9 \times 10^{4}$ & $1.25 \times 10^{2}$ & 99.569 \\
\hline 45 & $3.75 \times 10^{6}$ & $1.23 \times 10^{4}$ & 99.672 \\
\hline 46 & $3.88 \times 10^{6}$ & $2.50 \times 10^{2}$ & 99.994 \\
\hline 47 & $2.59 \times 10^{7}$ & $4.75 \times 10^{4}$ & 99.817 \\
\hline 48 & $1.84 \times 10^{5}$ & nd & 100.000 \\
\hline 49 & $1.93 \times 10^{6}$ & $2.88 \times 10^{3}$ & 99.851 \\
\hline 50 & $7.38 \times 10^{3}$ & nd & 100.000 \\
\hline
\end{tabular}

are high, sufficient virus can be expected to survive freezing and thawing; however, when virus concentrations are lower (as suspected for most apparently healthy fishes taken in the fishery), then a single freeze-thaw cycle may be sufficient to eliminate the virus. Although our data derived from a single observation, no virus was recovered upon inoculation of cell lines with thaw-water examined from the previously frozen block of experimentally infected sardine in our current study (S. Yun unpubl. data). This suggests that most virus stays in the fish tissues throughout the freezing and thawing process.

\section{CONCLUSIONS}

Certainly the movement of live fishes is a principal means by which fish pathogens have spread, and with modern modes of transport these can often comprise great distances (Hedrick 1996). Movements of frozen fishes also represent a risk factor for fish-pathogen dispersal, but the inherent losses in pathogen viability with freezing and thawing may significantly reduce this risk. Perhaps the best evidence that existing pathways are not conducive to the spread of VHSV to Australian waters is the present lack of detection of VHSV in South Australia despite over more than $10 \mathrm{yr}$ of baitfish importation at a rate of $250000 \mathrm{t} \mathrm{yr}^{-1}$ (Crane et al. 2000, Biosecurity Australia 2002). The apparent lack of establishment of VHSV in Australia may be the result of a number of factors associated with the baitfishes in question. Certainly, a low prevalence and concentration of virus in healthy, caught, wild fishes is initially important. Commercial freezing and thawing are then likely to further reduce the concentrations of virus present in the fish tissues. Lastly, restrictions that allow import only during times when local water temperatures are $15^{\circ} \mathrm{C}$ or greater probably decrease virus stability as well as virus replication. These and potentially many other host and environmental factors may all be acting in concert to prevent establishment of VHSV in South Australian waters.

Acknowledgements. This work was supported by the US Department of Commerce's National Oceanic and Atmospheric Administration under NOAA Grant through the Saltonstall-Kennedy Program (S-K Grant NA03NMF4270 161). The authors also thank the National Fisheries Institute for support in part of this study. This is Contribution Number 2289, Bodega Marine Laboratory, University of California at Davis.

\section{LITERATURE CITED}

Amos K, Thomas J, Hopper K (1998) A case history of adaptive management strategies for viral hemorrhagic septicemia virus (VHSV) in Washington state. J Aquat Anim Health 10:152-159

Avtalion RR, Weiss E, Moalem T (1976) Regulatory effects of temperature upon immunity in ectothermic vertebrates. In: Marchalonis JJ (ed) Comparative immunology. Blackwell, Oxford, p 227-238

Batts WN, Winton JR (1989) Enhanced detection of infectious hematopoietic necrosis virus and other fish viruses by pre- 
treatment of the cell monolayers with polyethylene glycol. J Aquat Anim Health 1:284-290

Biosecurity Australia (2002) Policy review of fish importation resulting from the discovery of viral haemorrhagic septicaemia virus (VHSV) in pilchards Sardinops sagax and mackerel Scomber japonicus from Californian waters: summary of technical information. Department of Agriculture, Fisheries and Forestry, Canberra

Castric J, de Kinkelin P (1984) Experimental study of the susceptibility of two marine fish species, sea bass (Dicentrarchus labrax) and turbot (Scophthalamus maximus), to viral haemorrhagic septicaemia. Aquaculture 41:203-212

Castro C, Arnold JJ, Cameron CE (2005) Incorporation fidelity of the viral RNA-dependent RNA polymerase: a kinetic, thermodynamic and structural perspective. Virus Res 107:141-149

Crane MStJ, Hardy-Smith P, Williams LM, Hyatt AD and 5 others (2000) First isolation of an aquatic birnavirus from farmed and wild fish species in Australia. Dis Aquat Org 43:1-14

Dalton R (2004) Fishing for trouble. Nature 431:502-504

de Kinkelin P, Scherrer R (1970) Le virus d'Egtved I. Stabilité, développement et structure du virus de la souche danoise $F_{1}$. Ann Rech Vet 1:17-30

de Kinkelin P, Bearzotti-Le Berre M, Bernard J (1980) Viral hemorrhagic septicemia of rainbow trout: selection of a thermoresistant virus variant and comparison of polypeptide synthesis with the wild-type virus strain. J Virol 36: 652-658

de Kinkelin P, Dorson M, Hattenberger-Baudouy AM (1982) Interferon synthesis in trout and carp after viral infection. Dev Comp Immunol (Suppl) 2:167-174

Emmenegger EJ, Troyer RM, Kurath G (2003) Characterization of the mutant spectra of a fish RNA virus within individual hosts during natural infections. Virus Res 96:15-25

Fijan N, Sulimanovic D, Bearzotti M, Muzinic D, Zwillenberg LO, Chilmoncyzk S, Vautherot JF, de Kinkelin P (1983) Some properties of the Epithelioma papulosum cyprini (EPC) cell line from carp Cyprinus carpio. Ann Virol 134: 207-220

Goodwin AE, Peterson JE, Meyers TR, Money DJ (2004) Transmission of exotic fish viruses: the relative risks of wild and cultured bait. Fisheries 29:19-23

Hedrick RP (1996) Movements of pathogens with the international trade of live fish: problems and solutions. Rev Sci Tech Off Int Epizoot 15:523-531

Hedrick RP, Batts WN, Yun S, Traxler GS, Kaufman J, Winton JR (2003) Host and geographic range extensions of the North American strain of viral hemorrhagic septicemia virus. Dis Aquat Org 55:211-220

Hershberger PK, Kocan RM, Elder NE, Meyers TR, Winton JR (1999) Epizootiology of viral hemorrhagic septicemia virus in Pacific herring from the spawn-on-kelp fishery in Prince William Sound, Alaska, USA. Dis Aquat Org 37:23-31

Isshiki T, Nishizawa T, Kobayashi T, Nagano T, Miyazaki T (2001) An outbreak of VHSV (viral hemorrhagic septi-

Editorial responsibility: Jo-Ann Leong,

Kaneohe, Hawaii, USA cemia virus) infection in farmed Japanese flounder Paralichthys olivaceus in Japan. Dis Aquat Org 47:87-99

Isshiki T, Nagano T, Miyazaki T (2002) Effect of water temperature on pathological states of Japanese flounder experimentally infected with viral hemorrhagic septicemia virus, a flounder isolate KRRV-9601. Fish Pathol 37:95-97

Kocan R, Bradley M, Elder N, Meyers T, Batts W, Winton JR (1997) North American strain of viral hemorrhagic septicemia virus is highly pathogenic for laboratory-reared Pacific herring. J Aquat Anim Health 9:279-290

Kocan RM, Hershberger PK, Elder NE (2001) Survival of the North American strain of viral hemorrhagic septicemia virus (VHSV) in filtered seawater and seawater containing ovarian fluid, crude oil and serum-enriched culture medium. Dis Aquat Org 44:75-78

Kurath G, Garver KA, Troyer RM, Emmenegger EJ, EinerJensen K, Anderson ED (2003) Phylogeography of infectious hematopoietic necrosis virus in North America. J Gen Virol 84:803-814

McFarlane GA, Smith PE, Baumgartner TR, Hunter JR (2002) Climate variability and Pacific sardine populations and fisheries. Am Fish Soc Symp 32:195-214

Meyers TR, Winton JR (1995) Viral hemorrhagic septicemia virus in North America. Annu Rev Fish Dis 5:3-24

Meyers TR, Short S, Lipson K, Batts WN, Winton JR, Wilcock J, Brown E (1994) Association of viral hemorrhagic septicemia virus with epizootic hemorrhages of the skin in Pacific herring Clupea harengus pallasi from Prince William Sound and Kodiak Island, Alaska, USA. Dis Aquat Org 19:27-37

Meyers TR, Short S, Lipson K (1999) Isolation of the North American strain of viral hemorrhagic septicemia virus (VHSV) associated with epizootic mortality in two new host species of Alaskan marine fish. Dis Aquat Org 38: 81-86

Mortensen HF, Heuer OE, Lorenzen N, Otte L, Olesen NJ (1999) Isolation of viral haemorrhagic septicaemia virus (VHSV) from wild marine fish species in the Baltic Sea, Kattegat, Skagerrak and the North Sea. Virus Res 63:95-106

OIE (Office International des Epizooties) (2003) Diagnostic manual for aquatic animal diseases. OIE, Paris (also available from World Organisation for Animal Health at www.oie.int/)

Parry L, Dixon PF (1997) Stability of nine viral haemorrhagic septicaemia virus (VHSV) isolates in seawater. Bull Eur Assoc Fish Pathol 17:31-36

Vestergård Jørgensen PE (1982) Egtved virus: occurrence of inapparent infections with virulent virus in free-living rainbow trout, Salmo gairdneri Richardson, at low temperature. J Fish Dis 5:251-255

Wolf P, Smith PE, Bergen DR (2001) Pacific sardine. In: Leet WS, Dewees CM, Klingbeil R, Larson EJ (eds) California's living marine resources: a status report. Deptartment of Fish and Game, University of California Press, Oakland, p 299-302

Submitted: April 13, 2005; Accepted: November 3, 2005

Proofs received from author(s): February 22, 2006 